
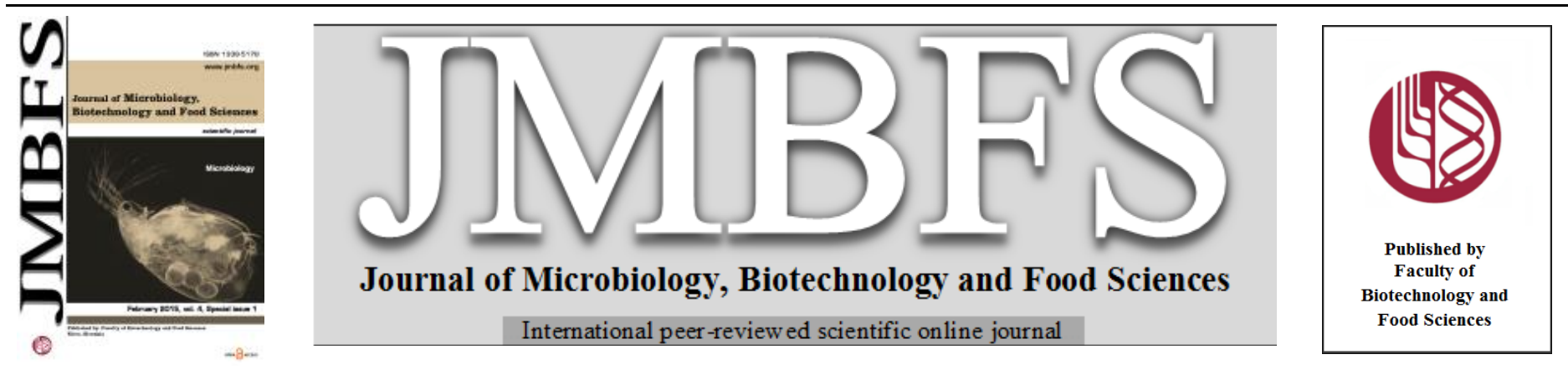

\title{
MICROBIOLOGY OF RAW MATERIALS USED FOR CONFECTIONARY PRODUCTION
}

\section{Jana Petrovál , Lubomíra Juhaniaková ${ }^{1}$, Margarita Terentjeva ${ }^{2}$, Simona Kunová ${ }^{3}$, Henrieta Blaškovičová $^{1}$, Miroslava Kačániovál $^{1}$}

\author{
Address(es): \\ ${ }^{1}$ Slovak University of Agriculture in Nitra, Faculty of Biotechnology and Food Sciences, Department of Microbiology, Trieda Andreja Hlinku 2, 949 76, Nitra, \\ Slovakia. \\ ${ }^{2}$ Latvia University of Agriculture, Faculty of Veterinary Medicine, Institute of Food and Environmental Hygiene, K. Helmaņa iela 8, LV 3007, Jelgava, Latvia. \\ ${ }^{3}$ Department of Food Hygiene and Safety, Faculty of Biotechnology and Food Sciences, Slovak University of Agriculture in Nitra, Trieda Andreja Hlinku 2, 94976 \\ Nitra, Slovak Republic.
}

*Corresponding author: miroslava.kacaniova@gmail.com

doi: 10.15414/jmbfs.2015.4.special1.52-56

\section{ARTICLE INFO}

Received 18.11. 2014

Revised 10. 12. 2014

Accepted 23. 12. 2014

Published 2. 2. 2015

\section{Regular article}

open ${ }_{\text {ACCESS }}$

\begin{abstract}
The aim of our study was to evaluate the microbiological quality of raw materials used for preparation of confectionery products. For microbiological evaluation total count of bacteria, mesophilic aerobic bacteria, coliform bacteria, yeast and microscopic filamentous fungi in samples of raw materials used in the manufacture and creams of confectionery products were detected. In addition to these groups of microorganisms the presence of pathogenic microorganisms Salmonella spp. and Staphylococcus aureus in creams was monitored. Products are assessed according to the limit values of the number of microorganisms defined in the Codex Alimentary of the Slovak Republic. For microbiological analysis of confectionery products, sampling of components of confectionary products and cream was carried out according to current health regulations and altogether 65 samples of components and creams were collected: 10 samples of raw materials sugar, 10 samples of flour, 10 samples of butter and 10 samples of eggs, 5 samples of butter yolk from cream-filled disposable bag without rum addition, 5 samples of butter yolk from cream-filled disposable bag with rum addition, 5 samples of creamfilled multiple use paid bag, 5 samples of cream-filled newly purchased paid bag, 5 samples of Venček corpus and 5 samples of the French cubes corpus. From raw material the highest TBC (2.65log CFU) was in flour, but the lowest in sugar ( $1.35 \log$ CFU), the highest years counts was found on flour (2.42), but lowest in butter (1.18), while wasn't in egg. In samples of creams and corpus were increased occurrence of yeast, coliform bacteria. Salmonella spp. and Staphylococcus aureus weren't isolated from any tested sample.
\end{abstract}

Keywords: Microorganisms, bacteria, filamentous microscopic fungi, raw material products

\section{INTRODUCTION}

The control of raw materials, processing and environment are critical factors in the prevention of microbial contamination of confectionery.

Food spoilage is an actual economic problem worldwide. Approximately onefourth of the world's food supply is lost through microbial activity alone (Huis in't Veld, 1998). This is linked to properties of the several components used in production of confectionary as milk, flour and sugar. Milk is a highly nutritious food that serves as an excellent growth medium for a wide range of microorganisms (Ruegg, 2003; Rajagopal, 2005). The microbiological quality of milk and dairy products is influenced by the initial flora of raw milk, the processing conditions, and post-heat treatment contamination (Richter et al., 1992). Undesirable microbes that can cause spoilage of dairy products include Gram-negative psychrotrophs, coliforms, lactic acid bacteria, yeasts, and molds. In addition, various bacteria of public health concern such as Salmonella spp., Listeria monocytogenes, Campylobacter jejuni, Yersinia enterocolitica, pathogenic strains of Escherichia coli and enterotoxigenic strains of Staphylococcus aureus may also be found in milk and dairy products. For this reason, increased emphasis should be placed on the microbiological examination of milk and dairy foods. Microbiological analyses are critical for the assessment of quality and safety, conformation with standards and specifications, and regulatory compliance (Vasavada, 1993).

White sugar has been used for ages in food production not only as a sweetener but also as a valuable ingredient contributing to the color, flavor and texture of food. Recently, world sugar production is about $160 \mathrm{Mt}$ per year and it shows a general tendency to increase. Further increase of world sugar production is still expected and, according to prognosis, in the year 2019/2020 may exceed $200 \mathrm{Mt}$ per year. World sugar production is based in $70 \%$ on sugar cane and in $30 \%$ on sugar beet, while in the European Union $98 \%$ of total sugar production comes from sugar beet (Nolte and Grethe, 2011; OECD-FAO, 2010).
Flour is generally regarded as a microbiologically safe product as it is a low water activity commodity. Although the growth of pathogenic bacteria may not be supported under such conditions, pathogens that contaminate flour may survive for extended period. There are few reported incidents of food poisoning resulting from contaminated flour. Australian, European and the USA studies indicate that Salmonella spp., Escherichia coli, Bacillus cereus and spoilage microorganisms are present in wheat and flour at low levels (Berghofer $\boldsymbol{e t}$ al. 2003). It is important to point out that Salmonella has been found to be the major hazard in confectionery. Testing for this organism at specific control points provides the best means of quality control. Constant surveillance and good manufacturing practice are the best methods for prevention of contamination (De Figueiredo, 2007).

In a controlled experimental setting, De Reu et al. (2005a, 2005b) found that levels of total aerobic microorganisms on eggs was 5.5-6.0 $\log$ CFU.mL ${ }^{-1}$. De Reu et al., 2009). Huneau-Salaun et al. (2010) found similar but less pronounced differences when they compared numbers of total aerobic microorganisms recovered from eggs. Another study conducted on a research farm found the opposite of De Reu et al. (2005b; 2009) and Huneau-Salaun et al. (2010) and reported that total aerobic microorganisms on eggs were $90 \%$ lower (2.25 and $2.75 \log 10$ CFU. $\mathrm{mL}^{-1}$, respectively) during both winter and spring (Jones et al., 2011).

The aim of our study was to evaluate the microbiological quality of raw materials use for preparation of confectionery products. For microbiological evaluation total count of bacteria, mesophilic aerobic bacteria, coliform bacteria, yeast and microscopic filamentous fungi in samples of raw materials used in the manufacture and creams of confectionery products were detected. In addition to these groups of microorganisms the presence of pathogenic microorganisms such as Salmonella spp. and Staphylococcus aureus in creams was monitored. 


\section{MATERIAL AND METHODS}

\section{Samples collection}

For microbiological analysis of confectionery products, we take adequate samples of intermediate products are carried out according to current health regulations. For microbiological analysis were collected 10 samples of raw materials sugar, 10 samples of flour, 10 samples of butter and 10 samples of eggs. Below were taken for microbiological examination samples of creams: 5 samples of butter yolk from cream-filled disposable bag without rum addition, 5 samples of butter yolk from cream-filled disposable bag with rum addition, 5 samples of cream-filled multiple use paid bag, 5 samples of cream-filled newly purchased paid bag, 5 samples of Venček corpus and 5 samples of the French cubes corpus.

\section{Determination of CFU counts}

For microbiological analysis the confectionary samples were processed immediately after collection. The total count of bacteria (TCB), mesophilic aerobic bacteria $(\mathrm{MAB})$, coliforms bacteria $(\mathrm{CB})$, yeasts $(\mathrm{Y})$, microscopic filamentous fungi (MF), Staphylococcus aureus (SA) and Salmonella spp. (SS) were assessed. Colony forming unit counting method was applied for quantitative determination of respective groups of microorganisms in $1 \mathrm{~g}$ of confectionery component materials. Plate Count Agar was used for CFU counting isolation of $\mathrm{TCB}$ and after inoculation agar was incubated for $48-72 \mathrm{~h}$ at $30{ }^{\circ} \mathrm{C}$ applying aerobic cultivation method. Meat peptone agar was used for MAB CFU counting and inoculated agar was incubated for $48-72 \mathrm{~h}$ at $25{ }^{\circ} \mathrm{C}$ applying aerobic cultivation method). Violet Red Bile agar was used for CB CFU counting by incubation of inoculated agar for $24 \mathrm{~h}$ at $37{ }^{\circ} \mathrm{C}$ applying aerobic cultivation method). DRBC and DG18 agars were used for Y and MF CFU counting by incubation of inoculated agars for $5-7$ days at $25^{\circ} \mathrm{C}$ applying aerobic cultivation method). XLD agar was used for isolation of Salmonella spp. by incubation of inoculated agar for 18-24 hour at $37 \mathrm{C}$ applying aerobic cultivation method) and Baird Parker agar was used for Staphylococcus aureus isolation by incubation of inoculated agar for $45-48$ hour at $35-37{ }^{\circ} \mathrm{C}$ applying aerobic cultivation method). All cultivating medium were obtained from Biomark ${ }^{\mathrm{TM}}$, Pune, India.

\section{Statistical analysis}

For data from each replication the mean was calculated and all data were $\log$ transformed. Statistical analysis was done with STATGRAPHICS 5 software (UMEX GmbH Dresden, Germany). For number of total count of bacteria (TCB), mesophilic aerobic bacteria (MAB), coliforms bacteria (CB), yeasts (Y), microscopic filamentous fungi (MF), standard deviation (SD) and coefficient of variability $(\mathrm{CV})$ were calculated.

\section{RESULTS AND DISCUSSION}

In this study were analyzed raw materials for confectionary products as sugar flour, butter and eggs. In next stage of microbiological butter cream samples and corpuses of Venček and French cubes were analyzed. Results of microbiological testing of raw materials - sugar, flour, butter, eggs, as well as samples of butter yolk from cream-filled disposable bag without rum addition, samples of butter yolk from cream-filled disposable bag with rum addition, samples of cream-filled multiple use paid bag, samples of cream-filled newly purchased paid bag, samples of Venček corpus and samples of the French cubes corpus are summarized in Fig. 1-10.

The microflora of sugar cane, depending on its type, is composed of many different kinds of microorganisms. Among them, the most often enumerated include the following microorganisms: bacteria: Bacillus spp., Flavobacterium spp., Pseudomonas spp. and Enterobacteriaceae; Xanthomonas spp. Lactobacillus spp. Saccharomyces spp., Torula spp. and Pichia spp.; $\quad$ and $\quad$ fungi: Penicillium spp., Actinomyces spp. and Streptomyces spp. (Martini etal., 2010; Wojtczak et al., 2012). The composition of the population of microorganisms is closely linked to the sugar content and $\mathrm{pH}$ of sugar cane. Immediately after cane sugar is cut, the microflora inside its stem is composed primarily of yeasts and bacteria: Leuconostoc spp., Xanthomonas spp. and Aerobacter spp. At the same time, rapid development of bacteria of the genus Leuconostoc, namely: $L$. mesenteroides and $L$. dextranicum may lead to the formation of sugar losses reaching up to $1.5 \%$ due to the production of acids, dextran and mucus (Cerutti de Guglielmone et al., 2002 and Eggleston et al., 2001).

Number of microscopic filamentous fungi, number of coliforms bacteria, mesophilic aerobic bacteria was not find in this study. All tested samples were according Codex Alimentarius CA SR (2009). Similar samples of butter were according to CA SR (2009). Average number of total count of bacteria in egg samples was $2.17 \log \mathrm{CFU} . \mathrm{g}^{-1}$, number of mesophilic aerobes bacteria was 1.85 $\log$ CFU. $\mathrm{g}^{-1}$ and microscopic filamentous fungi $0.23 \mathrm{log}$ CFU. $\mathrm{g}^{-1}$. Statistical significant differences of total count of bacteria were found among sugar, butter, sugar and flour, sugar and eggs, flour and eggs. Coliform bacteria, Staphylococcus aureus and Salmonella spp. were not found in these samples.
1.35

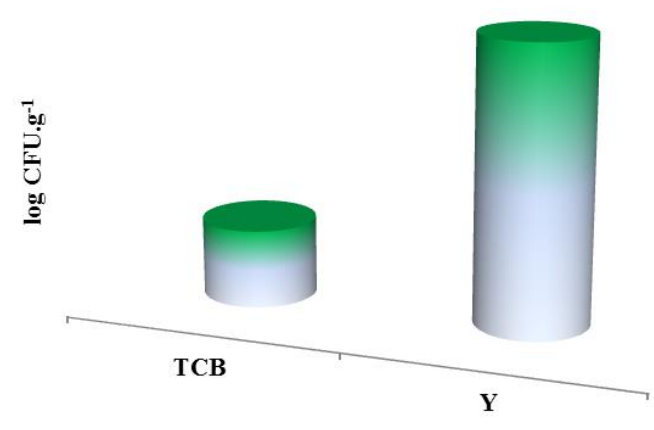

Figure 1 Microbiological quality of sugar samples

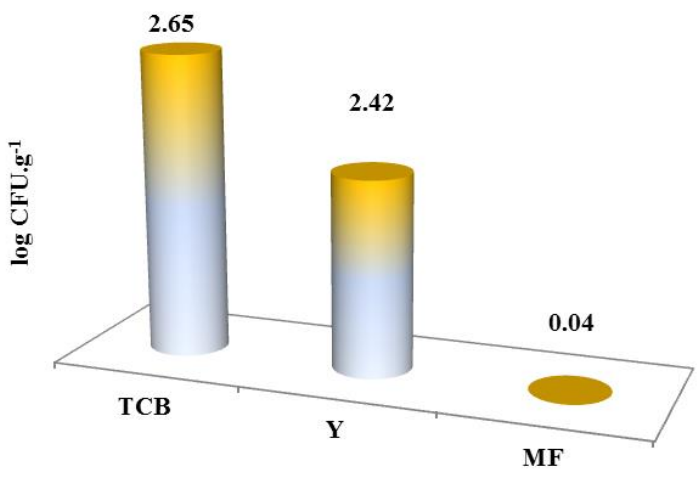

Figure 2 Microbiological quality of flour samples
Average number of total count of bacteria in flour samples was $2.65 \log$ CFU. $\mathrm{g}^{-1}$, number of yeast was $2.42 \log \mathrm{CFU} . \mathrm{g}^{-1}$ and microscopic filamentous fungi 0.04 $\log \mathrm{CFU} \cdot \mathrm{g}^{-1}$

The microflora of flour is composed of a variety of micro-organisms, including yeasts, moulds, psychotropic, thermophilic, and thermoduric bacteria, lactic acid bacteria, "rope bacteria", and pathogenic bacteria, more specifically $B$. cereus, $C$. perfringens, C. botulinum, and Salmonella spp. Although cereal grains and their milled products have rarely been implicated in foodborne disease (Deibel $\boldsymbol{e t}$ al., 2001), it is the large quantity of flour annually consumed and the associated significant exposure to these micro-organisms that prompted the retrieval of data on the frequency of pathogenic bacteria and microorganisms that would render the food unfit for the consumer. A number of studies on

wheat flour report mean total aerobic counts in the order of $10^{4} \mathrm{CFU} . \mathrm{g}^{-1}$ or below (Berghofer et al., 2003). Although the number of samples exceeding tota aerobic counts of $10^{4} \mathrm{CFU} . \mathrm{g}^{-1}$ in wheat flour can be very low (Berghofer $\boldsymbol{e t}$ al., 2003). Coliform bacteria and $E$. coli counts are important as these are indicative of the general hygienic properties of foodstuffs. Moreover, the presence of $E$. coli in a finished, ready-to-eat product can be a public health concern, as this finding may indicate deficiencies in process control (Deibel et al., 2001). In our study there were no coliforms in analyzed samples that indicate good microbiological quality of the product. Mean mould counts are usually around $10^{3} \mathrm{CFU} \cdot \mathrm{g}^{-1}$ (Potus and Suchet, 1989). Considerably higher levels of mould loads in cereal samples in Turkey, however, i.e. in the order of $10^{5}-10^{6} \mathrm{CFU} \cdot \mathrm{g}^{-1}$, have been reported by Aran and Eke (1987). There are different sources for moulds present in flour, for example fungi prevailing in the grain, the mill machinery itself, and/or a lower quality of sanitary control (Aydin et al., 2009). 


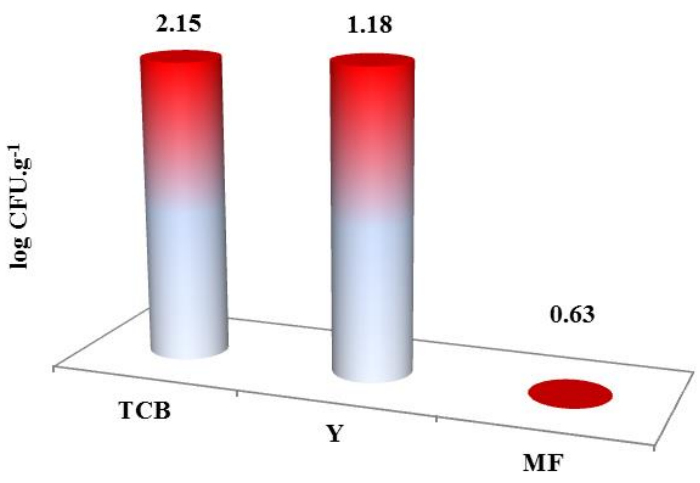

Figure 3 Microbiological quality of butter samples

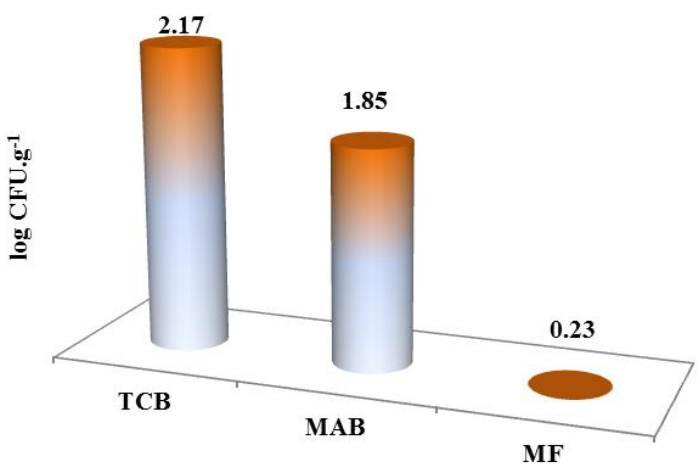

Figure 4 Microbiological quality of egg samples

Although the butter is not a highly perishable food, it does undergo spoilage by bacteria and molds. The main source of microorganisms of butter is cream, whether sweet or sour, raw or pasteurized (Jay, 1996). Yeast and molds are important spoilage microorganisms of butter and can result in surface discoloration and off-flavor. Psychrotrophic Gram negative bacteria may develop and result proteolytic and lipolytic changes (ICMSF, 2005). Microbiological analysis of butter for specific pathogens is not considered justified and testing is restricted to potential spoilage microorganisms; together with Escherichia coli and coliform bacteria (Varnam and Sutherland, 1993). The microflora of butter reflects the quality of cream, the sanitary conditions of equipment used to manufacture the butter and the environmental and sanitary conditions during packaging and handling of such product (Richter $\boldsymbol{e t}$ al, 1992). In our study, all of the samples were contaminated by total count of bacteria, yeasts and microscopic filamentous fungi. In previous studies, level of psychrotrophic counts were recorded by Ahmed et al. (1987) and Henin and Kaldes (1992) with mean values of $3.06 \times 10^{4}$ and $3.01 \times 10^{4} \mathrm{cfu}^{-1} \mathrm{~g}^{-1}$, respectively. On the contrary, none of the examined cooking butter samples contained detectable level of psychrotrophic bacteria $\left(<10 \mathrm{~g}^{-1}\right)$ was reported by El-Sherief (2007) Psychrotrophic Gram negative bacteria such as Pseudomonas spp. and Flavobacterium spp. may develop and cause off-odour formation and rancidity. Growth of Alteromonas putrefaciens or Flavobacterium malodoris may lead to surface taints very quickly affecting the mass of the product and accompanied by development of a putrid, decomposed or cheesy flavor that render the product unmarketable, leading to economic losses. The presence of molds and yeasts in butter are objectionable as they grow at a wide range of temperature and $\mathrm{pH}$ values resulting surface discoloration and off-flavor. However, of even more serious concern is that some molds are capable of producing toxic metabolites known as mycotoxins. Some of these toxins, such as aflatoxins, are known carcinogens (Meshref, 2010).

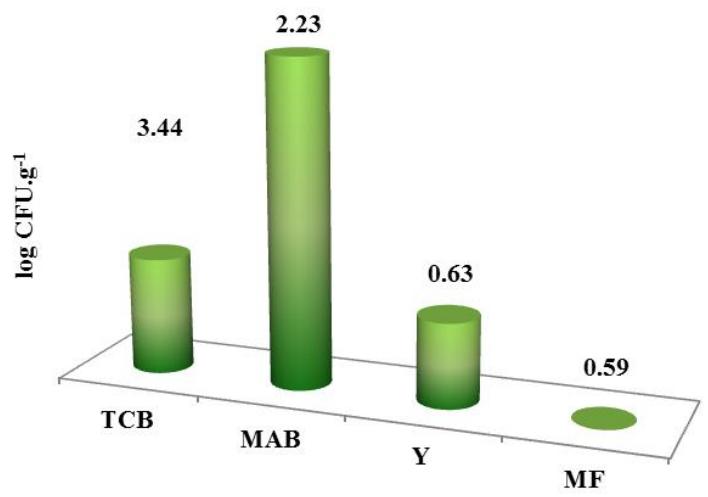

Figure 5 Microbiological quality of samplesbutter yolk from

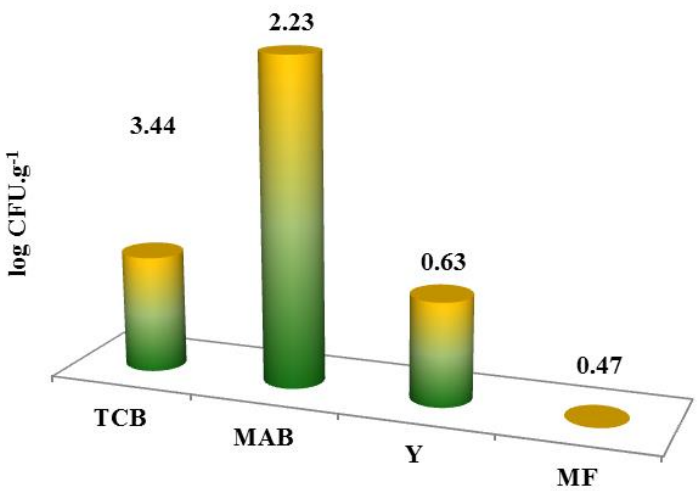

Figure 6 Microbiological quality of samples butter yolk cream-filled cream filled - disposable bag without rum addition disposable bag with rum addition

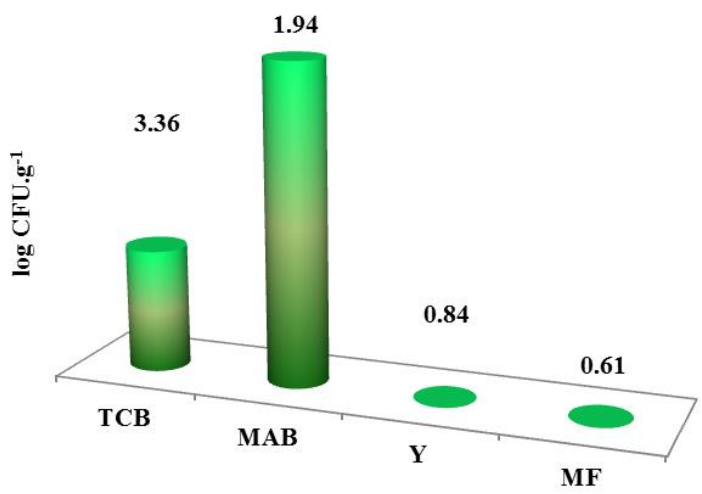

Figure 7 Microbiological quality of samples of cream-filled multiple

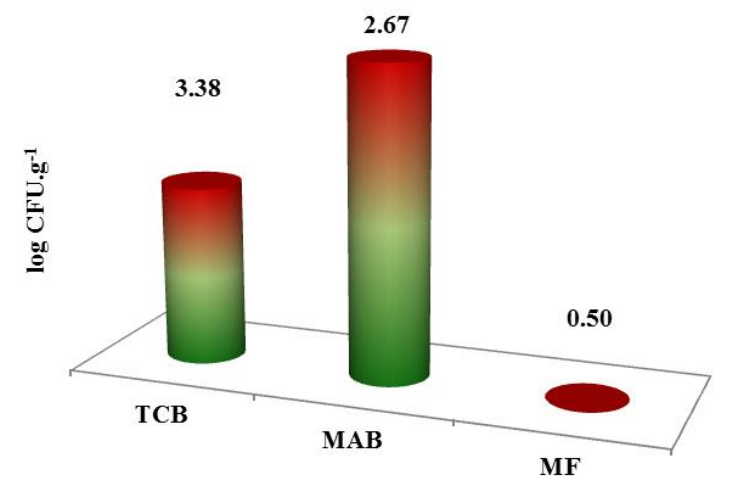

Figure 8 Microbiological quality of samples of cream-filled use of paid bagpaid bag newly purchased 


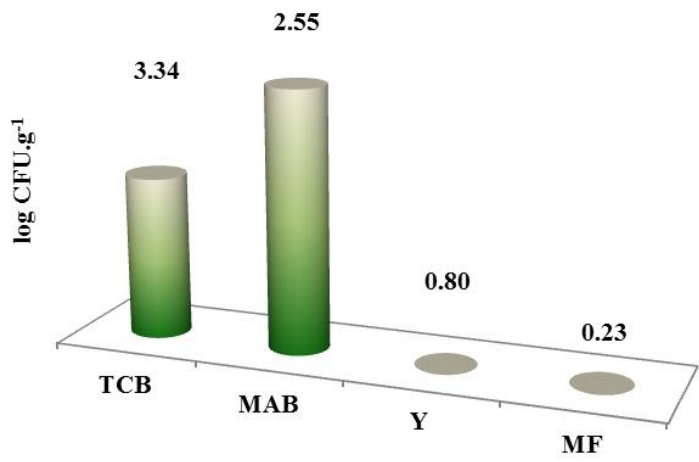

Figure 9 Microbiological quality of Venček corpus samples

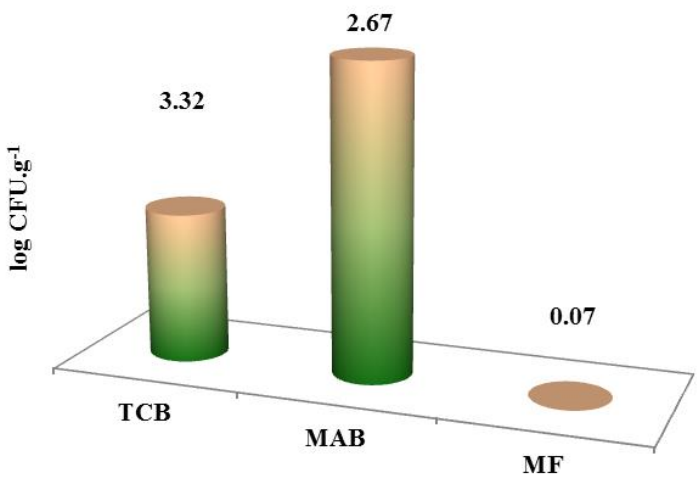

Figure 10 Microbiological quality of French cubes corpus samples

A high bacterial load present on the eggshell surface could increase the chance of eggshell penetration and contamination of internal contents

(Smith et al., 2000). Spiking method indicated that the limit of detection for Salmonella Infantis by culture method was approximately $1 \log$ CFU.ml ${ }^{-1}$. In the present study, shell rinse and crush methods were used to recover Enterobacteriaceae from commercial shell eggs as described earlier by Musgrove et al. (2005a,b). Limit of detection was not calculated for Enterobacteriaceae isolation/count from eggs. It is possible that the limit of detection of Enterobacteriaceae isolates from 11 different genera could be variable and further investigations are necessary to determine the detection limits of these different genera. Jones and Musgrove (2007) reported a higher Enterobacteriaceae count $\left(3.40 \mathrm{log}\right.$ CFU.eggshell $\left.{ }^{-1}\right)$ from eggshell wash. However, the study of Jones and Musgrove (2007) was conducted on restricted shell eggs which did not meet the quality standard for retail. As bacteria can move from eggshell surface into eggshell pores and further into egg internal contents, it is important to study the bacterial count in eggshell pores. De Reu $\boldsymbol{e}$ al. (2005a) and Protais et al. (2003) reported that there was no significant difference in eggshell contamination between beginning and end of the laying period in furnished cages or aviaries. Huneau-Salaün et al. (2010) found that eggshell contamination increased significantly with increasing age of flock but Mallet et al. (2006) reported that contamination decreased with age. However, both of these authors attributed the variation in their results to seasonal or environmental effects rather than flock age.

\section{CONCLUSION}

Comparing of the sugar microbiological quality with the requirements of the CA SR, we found that all of the sugar samples were with requirements of this type of raw material. Comparison of flour microbiological quality with CA SR, we found that all the samples were according with those requirements. Similarly, samples of butter were according with the requirements of the CA SR of this type of product. For creamy microbiology we don't have legislation, so we cannot compare this result. For future we recommended continue with research of products which are using for confectionary product production, because microbiological quality of this products can showing microbiological quality of confectionary product.

Acknowledgments: The paper was supported by the project: The research leading to these results has received funding from the European Community under project no 26220220180: Building Research Centre „AgroBioTech“ and by grant of VEGA 1/0611/14.

\section{REFERENCES}

AHMED, A.A.H., MOUSTAFA, M.K., ABDEL-HAKIEM, E.H. 1987. Sanitary condition of cooking butter manufactured in Assiut city. Assiut Veterinary Medicine Journal, 17(37), 79-86.

ARAN, N., EKE,D. 1987. Mould mycoflora of some Turkish cereals and cereal products. MIRCEN Journal, 3, 281-287.

AYDIN1, A., PAULSEN, P., SMULDERS, F.J.M. 2009.The physico-chemical and microbiological properties of wheatflour in Thrace. Turkish Journal of Agriculture and Forestry,33, 445-454. DOI:10.3906/tar-0901-20

BENNETT, R.W., BELAY,N. 2001.Bacillus cereus. Microbiological Examination of Foods, (Eds. PF Downes, K Ito), American Public Health Association, Washington DC, 311-324.

BERGHOFER, L.K., HOCKING, A.D., MISKELLY, D., JANSSON,E. 2003.Microbiology of wheat and flour milling in Australia.International Journal of Food Microbiology, 85, 137-149.DOI: 10.1016/S0168-1605(02)00507-X Cicognani G, Pedretti C, Cerrato A (1975) Caratteristiche microbiologiche delle farine di frumento. Industrie Alimentari 14: 60-64.

CODEX ALIMENTRIUS SR 2009. - Druhá čast', Štvrtá hlava Mikrobiologicképožiadavky na potraviny a na obaly na ich balenie. 2009. [on line]. [cit. 2009-11-07]. Available at: <http://www.svssr.sk/sk/legislativa/kodex.asp>.

DEFIGUEIREDO, P.M. 2007.Controlling microorganisms in confectionery products. Journal of Food Quality,2(2),143-147.DOI: 10.1111/j.17454557.1979.tb00664.x

DEIBEL, K.E., SWANSON, K.M.J.2001.Cereal and cereal products.Microbiological Examination of Foods, (Ed PF Downes, K Ito), American Public Health Association, Washington DC, 549-552.

DE REU, K., GRIJSPEERDT, K., HEYNDRICKX, M., UYTTENDAELE, M., HERMAN, L. 2005a.The use of total aerobic and gram-negative flora for quality assurance in the production chain of consumption eggs. Food Control, 16, 147 155.DOI: 10.1016/j.foodcont.2004.01.004.

DE REU, K., GRIJSPEERDT, K., HEYNDRICKX, M., ZOONS, J., DE BAERE, K., UYTTENDAELE, M., et al. 2005b.Bacterial eggshell contamination in conventional cages, furnished cages and aviary housing systems for laying hens. British Poultry Science, 46, 149-155.DOI: 10.1080/00071660500065359. DE REU, K., RODENBURG, T. B., GRIJSPEERDT, K., MESSENS, W., HEYNDRICKX, M., TUYTTENS, F. A. M., et al. 2009. Bacteriological contamination, dirt, and cracks of eggshells in furnished cages and noncage systems for laying hens: an international on-farm comparison. Poultry Science, 88, 2442-2448.DOI: 10.3382/ps.2009-00097.

EL-SHERIEF, K.A.H. Incidence, Economic and public health significance of Pseudomonas species in milk and some dairy products. Vet.Med., Beni-Suef Univ.; 2007. M.V.Sc. Thesis.

EYLES, M.J., MOSS, R., HOCKING, A.D. 1989.The microbiological status of Australian flour and the effects of milling procedures on the microflora of wheat and flour.Food Australia, 41, 704-708.

HENIN, A.Y., KALDES, Y.T. Microbiological evaluation of cooking butter manufactured in Minia Governorate. Beni-Suef Veterinary Medical Journal, 2(2), 291-297.

HUIS IN'T VELD, J.H.J. 1998. Microbial and biochemical spoilage of foods: an overview. International Journal of Food Microbiology, 33(1), 1-18 DOI:10.1016/0168-1605(96)01139-7.

HUNEAU-SALAUN, A., MICHEL, V., HUONNIC, D., BALAINE, L., \& LE BOUQUIN, S. 2010.Factors influencing bacterial eggshell contamination in conventional cages, furnished cages, and free-range systems for laying hens under commercial conditions. British Poultry Science, 51, 163-169.DOI $10.1080 / 00071668.2010 .482462$.

ICMSF, 2005. Microrganisms in Foods.Microbial Ecology of food commodities. Chap 11: Oil and Fat based foods. 2nd edition. New York: Kluwer Academic/ Plenum Publishers; 480-521

JAY J. Modern food microbiology. 5th edition. USA: Chapman and Hall publisher; 1996. Fermentation and fermented dairy products; pp. 131-148.

JONES, D. R., ANDERSON, K. E., MUSGROVE, M. T. 2011. Comparison of environmental and egg microbiology associated with conventional and free-range laying hen management. Poultry Science, 90, 2063-2068. DOI: 10.3382/ps.201001139 .

JONES, D.R., MUSGROVE, M.T. 2007. Pathogen prevalence and microbial levels associated with restricted shell eggs. Journal of Food Protection, 174 (70) 2004-2007.

MALLET, S., GUESDON, V., AHMED, A.M.H., NYS, Y. 2006. Comparison of eggshell hygiene in two housing systems: standard and furnished cages. British Poultry Science, 47, 30-35.

MESHREF, A.M.S. 2010.Microbiological quality and safety of cooking butter in Beni-Suef governorate-Egypt.African Health Sciences, 10(2), 193-198.

MUSGROVE, M., JONES, D., NORTHCUTT, J., HARRISON, M., COX, N., INGRAM, K., HINTON, A., 2005a. Recovery of Salmonella from commercial shell eggs by shell rinse and shell crush methodologies. Poultry Science, 84, 1955-1958.DOI: $10.1093 / \mathrm{ps} / 84.12 .1955$. 
MUSGROVE, M.T., JONES, D.R., NORTHCUTT, J.K., COX, N.A., HARRISON, M.A. 2005b. Shell rinse and shell crush methods for the recovery of aerobic microorganisms and Enterobacteriaceae from shell eggs. Journal of Food Protection, 68, 2144-2148.

NOLTE, S., GRETHE, H. 2011.EU and world sugar markets in 2010 . Zuckerindustrie, 136(2), 90-100.

OECD-FAO (Ed.), Agricultural outlook 2010, Organization for Economic Cooperation and Development, Paris (2010), pp. 131145 http://dx.doi.org/10.1787/agr_outlook-2010-en

OTTOGALLI, G., GALLI, A. 1979. Microbiological quality of flours: sour dough for bakery products and spaghetti. In Proceedings of the International Meeting on Food Microbiology and Technology (Eds. B Jarvis, JHB Christian, H Michener), Tabiabo (Parma), 141-153.

POTUS, J., SUCHET, P. 1989. Les problemes de microbiologie en meunerie. Industries des Cereales, 58, 27-33.

PROTAIS, J., QUEGUINER, S., BOSCHER, E., PIQUET, J.C., NAGARD, B. SALVAT, G., 2003. Effect of housing system on the bacterial flora in the air and on egg shells. Proceeding of the X European Symposium on the Quality of Eggs and Egg Products. St. Brieuc-Ploufragan, 142-149.

RAJAGOPAL, M., WERNER, B.G., HOTCHKISS, J.H. 2005. Low Pressure $\mathrm{CO}_{2}$ Storage of Raw Milk: Microbiological Effects. Journal of Dairy Science, 88, 3130. DOI: http://dx.doi.org/10.3168/jds.S0022-0302(05)72995-7.

RICHTER, R.L., LEDFORD, R.A., MURPHY, S.C. 1992. Milk and milk products. In: Vanderzant, C. and D.F. (Eds.). Compendium of methods for quality of refrigerating farm bulk tank milk-a review. 3rd Edn., Am. Public Health Assoc. : Washington DC., 837-838.

RICHTER, K.S., DORNEANU, E., ESKRIDGE, K.M., RAO, C.S. 1993. Microbiological quality of flours.Cereal Food World. 38, 367-369.

RUEGG, P.L. 2003.Practical Food Safety Interventions for Dairy Production Journal of Dairy Science, 86, E1-E9.DOI:10.3168/jds.S0022-0302(03)74034-X SMITH, A., ROSE, S.P., WELLS, R.G., PIRGOZLIEV, V. 2000. The effect of changing the excretamoisture of caged laying hens on the excreta and microbial contamination of their egg shells. British Poultry Science, 41, 168173.DOI: $10.1080 / 713654903$.

SPICHER, G. 1986. Merkpunkte für die Beurteilung der mikrobiologischhygienischen Qualitat von Weisenmehlen. Die Mühle \& Mischfuttertechnik, 33 , 449.VARNAM AH, SUTHERLAND JP. Milk and milk products. 1st edition. London: Chapman and Hall publisher; 1994. Butter margarine and spreads; 224 274.

VASAVADA, P.C. 1993.Rapid methods and automation in dairy microbiology. Journal of Dairy Science, 76, 3101-31013.

WOJTCZAK, M.; BIERNASIAK, J.; PAPIEWSKA, A. 2012.Evaluation of microbiological purity of raw and refined white cane sugar.Food Control, 25(1), 136-139. DOI:10.1016/j.foodcont.2011.10.031 